\title{
What Are They Speaking for: The Relative Participation of Female Councillors on Influencing "Health Related Female Interests" in the Decision Making Processes
}

\author{
Idda Lyatonga Swai ${ }^{*}$, Mackfallen Giliadi Anasel² \\ ${ }^{1}$ Department of Local Government Management, School of Public Administration and Management, Mzumbe University, \\ Mzumbe, Tanzania \\ ${ }^{2}$ Department of Health Systems Management, School of Public Administration and Management, Mzumbe University, \\ Mzumbe, Tanzania \\ Email: *ilyatonga@mzumbe.ac.tz
}

How to cite this paper: Swai, I. L., \& Anasel, M. G. (2020). What Are They Speaking for: The Relative Participation of Female Councillors on Influencing "Health Related Female Interests" in the Decision Making Processes. Advances in Applied Sociology, 10, 11-22.

https://doi.org/10.4236/aasoci.2020.102002

Received: December 10, 2019

Accepted: January 19, 2020

Published: January 22, 2020

Copyright $\odot 2020$ by author(s) and Scientific Research Publishing Inc. This work is licensed under the Creative Commons Attribution International License (CC BY 4.0).

http://creativecommons.org/licenses/by/4.0/

\section{(c) (i) Open Access}

\begin{abstract}
The usefulness of the increased number of women in the decision making bodies is seen when female interests are voiced in the decisions of the council. This implies that female interests may be better served if women are given decision making capabilities to raise their voice in the decision making bodies. This paper seeks to answer the question that "how and to what extent female councillors participate on health related female interests during decision making processes". The data used in this paper were collected from 2012 to 2014 for the $\mathrm{PhD}$ thesis titled "The relative participation and influence of female councillors in the decisions of the councils in Tanzania". The study involved a total of 128 councillors from the four LGAs and three methods of data collection that are the review of minutes of meetings, observation and interview were used. Quantitative and qualitative analytical methods were performed to acquire a better picture of the differences in councillors' participation, their perceptions, practice and experiences in the council. Although female councillors tried to promote health related issues in the council, there is no significant difference when compared to male councillors. Health related issues are not only a concern of female councillors, but also male councillors although their intentions may differ. The hypothesis that female councillors will participate more in health issues than male councillors is not supported. This concurred with the observation and interviews results except in some few scenarios where tension rises when women councillors tried to promote health related female interest but opposed by male council-
\end{abstract}


lors. Based on these results, the paper concludes that being female or male does alter the amount of councillors' participation in health issues. There were differences noted among the councillors concerning their assessment of councillors' participation in health that the majority of councillors expected female councillors, especially the special-seat councillors, to participate more in health related issues than male councillors. However, this was not confirmed and therefore there is no deviation on the participation in health related issues among the councillors. This indicated that health related issues are not only of interest to female councillors, but also to male councillors. Confidence building workshops for women political aspirants as well as the women who are already in the decision making organs are recommended to build their confidence and possibly increase participation of female councillors in the male dominated decision making bodies.

\section{Keywords}

Female Councillors Participation, Health Related Issues, Local Councils, Tanzania

\section{Introduction}

There is no doubt that quota systems in many countries have led to the increased number of women representatives in the decision making bodies, although the usefulness of those numbers in improving actual participation of women especially in advocating female issues and interests has been questioned by some scholars such as (Meena, 2009; Hicks, 2011; Yoon, 2011). While numbers are used as an important criterion, they are only a starting point in assessing female participation and influence in decision-making process. Female issues and interests would be better represented if women were empowered to participate in the decision making and raise their voice.

Female interest is operationalised in this paper as the concerns or problems that affect women in general, children regardless they are girls or boys and all old people. The concerns might be issues that are related to water and sanitation, health such as maternal health care, HIV/AIDS services, home based care, early pregnancy, family planning, food insecurity, access to quality and timely health care during delivery, girls' education and child welfare. All these are referred as "women issues" or female interest. When these services are not available in the community, women are likely to be negatively affected. Health related female interests are issues such as maternal health, infant, child and under- 5 services, HIV/AIDS services, early pregnancy, family planning, Community Health Fund (CHF), cervical and breast cancer, women delivering in a health facility, youth's and adolescents' sexual and reproductive health and general health. The assumption is that the participation of female councillors will be higher in these issues as compared to the participation of male councillors. If councillors, particularly female councillors will be the champion in speaking on health related 
issues, the Primary Health Care will be given priority in the council and automatically improved. This was evidenced in Uturo Village at Mbarali District in Mbeya Region where the community members particularly women decided to mobilise themselves to address the issue of maternal and infant mortality. Such practice was reported to turn the high level of maternal and infant deaths into zero (0) for about seventeen (17) year in Uturo village.

This is one of the good practices organised by the community members themselves and if the councillors particularly female councillors will support and cooperate with this kind of initiatives then many problems related with Primary Health Care will be voiced in the decisions of the councils and addressed accordingly. Therefore, the paper seeks to answer the general research question that How and to what extent female councillors participate on health related female interest's / women issues during decision making processes?

In 1980s Tanzania has adopted the policy that ensures that the women are represented in decision making bodies by introducing quota system (Mushi, 2011; Mkilanya, 2011). The reason behind quota system is to increase the number of women in decision-making bodies. The assumption is that if women are better represented in terms of numbers then the decision-making and its result is likely to change. First, new issues related to women interest particularly health related issues will be placed on the agenda. Second, some issues will get more attention. And third, female perspectives will be added to existing issues. It is assumed that female councillors will prioritize female interest during the decision making in the councils. Female councillors will then participate when these issues are on the table more than male councillors. This leads to the hypothesis that "female councillors will participate more in health related issues than male councillors".

\section{Theoretical Framework}

Many countries, particularly in the developing world, have established a quota system with the aim of increasing the number of female members for representative bodies (Dahlerup, 2005). In the 1980s Tanzania set aside special seats for women in parliament and councils and implemented through a quota system popularly known as a "special-seats arrangement" (Mushi, 2011; Mkilanya, 2011). At the local council, the quota system was originally established by the Local government (urban and rural authority) Act 1982 (URT, 1982). Later, in 1992, it was enshrined in the amendment of Constitution of United Republic of Tanzania. The initial objective of quota system was not only to balance the numbers of men and women in decision making, but with a broader intention to break down male dominance. The quota system was also expected to shape the circumstances that the interests of women might be better addressed and served in the decision making. With a larger group of women in the decision-making bodies, that is having at least $30 \%$ and above, the voices of the female half of the citizenry were expected to be heard (Meena, 2003). 
The changes in Constitutional amendment and laws have been followed by the increase of the number of women in representative organs. For example, the number of female councillors appointed under the special-seats arrangement increased from 926 in 2000 to 1184 in 2010 (URT, 2010). As of January 2012, nationwide 1302 out of the 4449 councillors were women. This is about $29 \%$ of the total seats available. Of these 1302 female councillors, 190 were elected, while 1112 councillors ( $25 \%$ of the total number) were special-seat female councillors appointed under the quota system. This number increased in the general election of 2015 and by then there are 1408 special-seat councillors $(26.2 \%$ of all councillors) in the LGAs. The country's ultimate goal is to have at least $50 \%$ female members at national-parliament and local councils which is in line with the requirement of African Union and the SADC.

While the question of equal representation particularly about numbers and percentages of male and female in decision making organs captivated a lot of debate, far less attention has been paid to the qualities of the increased numbers (Misafi, 2014; Tripp \& Kang, 2008). What women do after accessing decision making positions and if the increase in numbers of female representatives contributes to a better manifestation and promotion of women's interests and issues was not given enough attention (Mushi, 2011). The presence of (more) women in decision making bodies is expected to further the interests of women and to result in more equitable policy outcomes (OXFAM, 2008). However, the evidence that the advancement of women's interests has improved with increased number of female representatives is lacking. There have been cases where women were reported to have fear of speaking especially when they are surrounded by men (Dahlerup, 2002). The question is if women are not comfortable to speak in the presence of men, how the interests that are considered to be "female interests" be addressed?

The expectation of a successful quota system is the recruitment of women, capable of overcoming the existing political culture and speaks out issues related to interests of women as individuals or as a group (Dahlerup, 2002). Leaving aside the complexity question of whether the interests of women cannot be the interest of men, the success of the quota system would depend much on whether the female councillors would indeed manage to influence the decision making. However, there are very few literatures such as Swai (2017) that provide information on actual participation and resulting influence of female councillors in health related decisions at councils in Tanzania.

But how the female councillors can participate and influence the decisions? All councillors have an equal opportunity to participate in the committee and council meetings. The council receives and discusses issues that were initiated and discussed in the village council, compiled in the Ward Development Committee (WDC) and then the councillors had a chance to debate them in the committees. The council executes its responsibilities through standing committees and other statutory sub-committees. A committee is an organ of the council and they are available in both rural and urban councils as indicated in Table 1 . 
Table 1. The standing committees of urban and rural LGAs.

\begin{tabular}{cc}
\hline Urban LGAs & Rural LGAs \\
\hline 1) Finance, administration and planning & 1) Finance and administration \\
2) Health, education and water & 2) Economic affair, education and health \\
3) Economic affairs, works and environment & 3) Urban planning and environment
\end{tabular}

Each standing committee in the council has a specific mandate and tasks that reflects one of the functions of the LGA. For instance, the provision of Primary Health Services is vested to LGA and they are discussed and decided in the standing committees of Health, Education and Water and Economic affairs, Education and Health in urban and rural LGAs respectively and the Council Health Management Teams (CHMT) prepare the Comprehensive Council Health Plan (CCHP) to guide the provision of district health services. Apart from the standing committees, each LGA may have other statutory sub-committees that may be established with a specific purpose such as a sub-committee to deal with the issues of HIV/AIDS, work and ethics and any other issues deemed necessary by the council. It is in this institutional framework that the female councillors are expected to speak out their voice to health related issues than male councillors.

\section{Methods}

The information concerning how and to what extent the female councillors participate in health issues in the decisions of the council is derived from the data collected from 2012 to 2014 for the PhD thesis by the corresponding Author. The data were collected from four councils in Tanzania including Ilala Municipal Council (MC), Mkuranga District Council (DC), Iringa MC and Iringa DC. Unit of analysis of the study was the councillor in the LGA and the study population consists of 128 councillors. The content analysis was done to count down all attempts made by female and male councillors in health issues during decision making processes. A total of 192 committee and council meetings minutes were reviewed identify and count down the attempts made by male and female councillors. The review was guided by a checklist developed before data collection and improved in the process of collecting data. This was followed with descriptive statistics and an independent samples t-test. Descriptive statistic was used to know the distribution of the dependent variable (health) among 128 male and female councillors of four LGAs. An Independent samples t-test was performed to answer the question whether observed differences in participation between male and female was significant.

In addition, 28 committee and council meetings were observed to obtain a full description of what the councillors do and to understand what really transpires in the course of making each decision in the council. Observation involved recording all interactions using a checklist. The purpose was to see how male and 
female councillors make attempts, the techniques they use and the challenges they face when participating in decision making. Moreover, 45 councillors were interviewed to gain a perspective from the councillors' themselves and their experiences of participating in the decision making. The aim was to understand the perception of individual councillors, the practice, challenges and experiences related to their participation and influence in council decisions and particularly in health related issues. The conclusions drawing from the interviews and observation were used to indicate councillors' views, perception and experience regarding participation and influence in the council.

\section{The Findings}

The central question that the paper seeks to answer is how and to what extent the female councillors participate in health related issues during decision making processes in the council. This is guided by an assumption that female councillors will participate more in health related issues than male councillors. The policy theory of the quota system in Tanzania assumes that women have interests that may to some extent differ from male interests. It is only through proper representation by women that these interests specific to women will be articulated in representative organs. "Women issues" or female interests are affiliated with social services such as water, maternal and child health \& HIV/AIDS services, home based care, early pregnancy, family planning, general health girls' education and child welfare. There are basically one dependent variable and one independent variable in the hypotheses addressed in this paper. The variables are (1) councillors' participation in health related issues and (2) councillors' sex. An overview of the distribution of the variables is presented in Table 2.

Table 2 shows the groups of male and female councillors and the attempts they made in health issues. The table also shows that there seems to be a difference regarding the number of attempts. The number of councillors participated in health related issues are only 49 out of 128 councillors. Only 31 out of 77 male councillors and 18 out of 51 female councillors made 76 and 58 attempts respectively. Then the question is whether there is a significant difference on the participation of male and female councillors in health related female issues? The issue is whether being a man or a woman matters for councillors' participation in health services. The paper attempted to answer this question by comparing the degree of participation in health services by male councillors with that of female councillors.

The comparison of mean participation in health issues by the group of male and the group of female councillors found that there is no significant difference between the degree of participation in the area of health by male and female councillors. The average degree of participation in this issue area by women is higher than that of men as shown in Table 3. But the difference is not significant. Based on this result the hypothesis that female councillors will participates more in health issues than male councillors are not supported. 
Table 2. The distribution of councillors' attempts in health issue areas (N 49).

\begin{tabular}{ccccccc}
\hline Issue areas/councillors & \multicolumn{2}{c}{ Male councillors (N 31) } & \multicolumn{2}{c}{ Female Councillors (N 18) } & \multicolumn{2}{c}{ Total } \\
\hline & Attempts & $\%$ & Attempts & $\%$ & Attempts & $\%$ \\
Health services & 76 & 57 & 58 & 43 & 134 & 100 \\
\hline
\end{tabular}

Table 3. Sex and councillors' participation in Health Issues.

\begin{tabular}{ccc}
\hline Sex & Mean (SD) & Relevance \\
\hline Male councillors & $.99(.37)$ & NS \\
Female councillors & $1.10(.31)$ & \\
& $p=.79, \mathrm{t}=-.267$ (two-tailed) & \\
\hline
\end{tabular}

This result is more or less supported by the observations and interviews where many of the interviewed councillors held the view that their participation in health is alike despite some few scenarios. 16 out of 45 interviewed councillors claimed that there is no major disparity between male and female councillors' participation in health issues and this was clarified by an elected female councillor from Iringa DC who stated that:

"We all work as councillors regardless of the differences in the way we were selected and political affiliation. When it comes to participation in the meeting, we contribute in all issues just like what men do." (R3)

Nevertheless, some councillors said that they expected female councillors particularly special-seat councillors would participate more in health issues than other councillors, since they were appointed to represent women in the council. 29 out of 45 interviewed councillors held the view that female councillors do participate more in health than male councillors. For instance, a special-seat-councillor in Iringa MC had the following to express during the interview:

"In rare cases male councillors contribute on the issues that are typical related to women such as water, and health-maternal and child health, but female councillors appears to contribute more than male in these issues." (R23)

About 29 councillors who claimed that women councillors participate more in health than men councillors, 12 councillors went further and specified that the special-seat councillors are the ones who participate more in health than other councillors. The councillors had the opinion that the special-seat councillors participate more in health than men, because they were appointed on the basis of sex to represent women. This has led to a further analysis to see whether the councillors appointed through quota system well known as special seats programme will participate more in health issues than the councillors elected from the wards. Although there are differences on the number of attempts made by elected councillors and special-seat councillors, the result (Table 4) shows that difference is not significant. These results do not support the experience shared by the councillors that the special seats councillors' attempts in health issues are likely to be higher compared to the attempts of elected councillors. 
Table 4. The status of councillors and their participation in Health Issues.

\begin{tabular}{ccc}
\hline Sex & Mean (SD) & Relevance \\
\hline Elected councillors & $1.10(.37)$ & NS \\
Special-seat councillors & $.86(.31)$ & \\
& $p=.98, \mathrm{t}=-.54$ (two-tailed) & \\
\hline
\end{tabular}

The councillors thought that the experience the women have from the community would make most out of female councillors so that they are much more dedicated to the so-called women's issues particularly health issues. This was confirmed by the opinion shared by some female councillors who said that they even have a political ambition to be a chairperson of a committee dealing with social services that included health issues. The councillors felt that being a chairperson of this committee would help them to be in touch with women in the ward and that they can fully participate in the decision to improve on the so-called women issues-health included. A special-seat councillor from Mkuranga DC expressed that:

"I would wish to be a chairperson of the committee dealing with health matters ... I think it is a committee where I can meet women easily especially when we go to visit projects in the ward and I can participate in the decisions to improve and save the life of women and the society as a whole." (R43)

The observations of committee and council meetings in the councils also found that the participation of councillors in health issues is almost equal. However, there were some scenarios noted that suggested female councillors attempting and trying to realise health issues in the decision making, while male councillors were observed to obstruct them. For example, whereas the female councillors in Mkuranga DC were active proposing and supporting the construction of a kitchen in the district hospital, male councillors were also participating on the same issue, but obstructing the construction of the kitchen. It was further noted that all female councillors supported the construction of the kitchen and were actively defending the proposal, whilst all male councillors participated opposed the proposal, arguing that the kitchen was not an urgent issue and that the council did not have the money for that. For this case, participation is counted for both male and female councillors and therefore there is no difference found.

It was also noted that both male and female councillors were active in the discussion on whether to buy or renovate the ultrasound machine and CD4 count machine for diagnosing HIV. Most of the female councillors said that it is worth to have at least two machines. They proposed to renovate the current ultrasound and to buy a new one. The councillors clarified that if the hospital will have two ultrasound machines, many more pregnant women will have access to ultrasound services and that will reduce pregnancy related complications. While female councillors were busy arguing to get the proposal accepted, male councillors on contrary were insisting that it is enough to have only one machine i.e. 
to renovate the existing machine. Although the arguments of male and female councillors were different, they were all still participating and this might be a reason for the findings that indicated insignificant results. In terms of number of attempts in health issues, there is no significant variation between male and female councillors. The difference was noted on the intent of the attempts. The councillors just have different opinions that female councillors trying to support issues related to health as observed in the two scenarios, while male councillors were busy trying to oppose them.

\section{Discussion}

The paper examines how and to what extent the female councillors participate in health issues in the decision making process in the councils. The councillors had different views regarding their assessment of councillors' participation in health issues. The majority of councillors expected female councillors to participate more in health issues compared to male councillors. This is in line with OXFAM (2008) that the presence of women in the decision making is expected to further the issues related to women and thus results in a more equitable policy outcomes. In addition, some councillors expected no variation relating to participation in health. The results showed that female councillors did not participate as much in health as they had expected.

Observation in the councils revealed that all the councillors who are a member of the social service committee among others dealing with health participated in the meeting. There were no differences in the amount of participation between the male councillors and the female councillors but there were differences as far as the intent of the participation was concerned. In the social service committee meeting in Mkuranga DC, female councillors were observed to make initiatives to improve health services in the council while male councillors opposed the initiatives of female councillors. In other words, male and female councillors not so much differed in the quantity of attempts identified and counted, but they were different in the intentions of their attempts. For instance, a proposal submitted by a female councillor to construct a kitchen in the district hospital was supported by many women, while the men were opposing the same proposal.

From this argument it follows that the quantitative measurement used may be not specific enough to measure the differences between male and female councillors concerning their policy interests when it comes to health issues. Qualitative data indicates that the amount of participation in health does not differ, but the type of attempt in health does. It is likely that the issues of health services are not only of interest to female councillors, but also to male councillors. Health issues is about making decisions on maternal and child health care, HIV/AIDS services, early pregnancy, family planning and general health to mention few. These issues are not only affecting women, but directly or indirectly to men. For instance, male councillors might be interested to participate in the issue of kitchen construction in Mkuranga DC because this decision will have impact on 
the budget as a whole. The female councillors too might be interested to participate, since this is considered to be a woman's issue as it will serve mostly women. So the intentions might differ, but the actual participation is then equal.

The basic idea underlying the quota system is that numbers matter (Swai et al., 2013). More in particular, it is expected that the focus of attention in the decision making would change as the number of women in decision making increases. Only a small glimpse of the effect of female participation on the agenda of the council particularly in health issues was captured. As a proxy for what is called "women's issues" the policy item of "health services" was chosen. The assumption derived from the general approach was that female councillors would make more attempts in this area than male councillors since it contains many issues that pertain to the interests of women. However, the operational assumption could not be confirmed with this analysis. These results are in line with Dahlerup (2002) who reported a fear of speaking among women representatives especially if they are surrounded by men. Indeed, both from observations and from interviews shows the image that female councillors are particularly active concerning issues in the health services domain. Most of the interviewed councillors said that female councillors do participate more in health than their male colleagues. Female councillors themselves, particularly the special-seats councillors professed an interest in health issues and this was confirmed by their wish to be a member or if possible a chairperson of the social service committee. They further clarified that they want to have an opportunity to decide on their social services and health in particular and give them power to promote projects that would improve health services in the society.

Moreover, female councillors do push a female agenda in health issues. This was confirmed in Mkuranga DC when female councillors proposed to construct a kitchen in the district hospital. Many of the members of this committee participated in the discussion about the proposal. All the female councillors supported it, while most of the male councillors were opposing. The argument of the female councillors was that the kitchen was going to be very useful in particular for women and poor people who remained in the hospital for long periods of time, even a few months. Male councillors on the contrary were arguing that it is not feasible to use council money to do something which is not in the council plan. This observation illustrates the tension that typically rises when women are trying to promote women's issues opposed by male councillors.

\section{Conclusion}

The main goal of the paper was to examine how and to what extent the female councillors participate in health issues in the decision making process in the councils. Based on results from the minutes of meetings, observation and interviews, the paper concludes that sex does alter the degree of councillors' participation in health issues. The alternative hypothesis that female councillors will participate more in health issues than the male councillors is not supported. 
There were disparities among the councillors regarding their assessment of councillors' participation in health. Many councillors expected female councillors, particularly the special-seat councillors, to participate more in health than male councillors. However, this was not confirmed in this study and therefore there is no variation relating to participation in health related issues among the councillors. This suggests that health related issues are not only of interest to female councillors, but also to male councillors. Male councillors might be interested to participate in the issue of health, because its decision will have impact on the budget of the council and female councillors too might be interested to participate, since this is considered to be a woman's issue as it will serve mostly women. So the intentions here might differ, but the actual participation is then equal. The focus of attention in the council agenda was expected to have new issues related to women that were not on the agenda of the council before, and female perspectives would be added to the existing issues as the number of women increases in the decision making organs.

Although female councillors tried to push female related health issues among others, still male councillors were found to be busy obstructing them and thus pushing women issues or adding women perspectives on the council agenda has been a challenge. This implies that the increased number of women in the decision making is not reflected in the actual participation of female councillors in the decision making. This further reflects that the policy goal to increase women representation in the decision making is not accompanied with a motive to capacitate and empower female representatives to speak on issues related to women. To make this possible, this paper recommends confidence building workshops for women political aspirants as well as the women who are already in the decision making organs to build their confidence that will automatically increase female participation in the male dominated decision making bodies.

\section{Conflicts of Interest}

The authors declare no conflicts of interest regarding the publication of this paper.

\section{References}

Dahlerup, D. (2002). Using Quota to Increase Women's Political Representation, International IDEA's, Women in Parliament, beyond Numbers. Stockholm: International IDEA.

Dahlerup, D. (2005). Increasing Women's Political Representation: New Trends in Gender Quotas. Women in Parliament: Beyond Numbers 141.

Hicks, J. (2011). Strengthening Women's Participation in Local Governance: Lessons and Strategies. Community Development Journal, 46, 136-150. https://doi.org/10.1093/cdj/bsq048

Meena, R. (2003). The Politics of Quota in Tanzania. A Paper Presented at the International Institute of Democracy and Electoral Assistance. IDEA Publication.

Meena, R. (2009). Women Participation in Positions of Power and Influence in Tanzania. 
Dar Es Salaam, Tanzania.

Misafi, H. P. (2014). Women's Participation in Decentralized Local Governance: The Case of Pastoral and Non-Pastoral Women in Kondoa Local Authority, Tanzania. Afrika Fokus, 27, 87-97. https://doi.org/10.21825/af.v27i2.4887

Mkilanya, V. M. (2011). The Substantive Representation of Women in the Tanzanian Parliament. Master's Dissertation, Dublin: Dublin City University.

Mushi, A. (2011). Achieving Gender Parity in Political Participation in Tanzania. Dar Es Salaam, Tanzania: Tanzania Gender Networking Programme.

OXFAM (2008). Women Leadership and Participation: Overview, Programme Insight, Oxfam $G$.

Swai, I. L. (2017). The Relative Participation and Influence of Female Councillors in the Decisions of the Councils in Tanzania. Groningen: Vakgroep Bestuursrecht \& Bestuurskunde. https://www.rug.nl/research/portal/files/40484103/completethesis.pdf

Swai, I. L., Masue, O. S., \& Anasel, M. G. (2013). Achievements and Challenges of Women Special Seats Arrangement in Tanzania. Journal of Policy and Leadership, 2, 121-135.

Tripp, A., \& Kang, A. (2008). Female Representation: The Global Impact of Quotas. Newbury Park, CA: Sage Publications.

URT (1982). Local Government Act Number 7 \& 8, Government Printer.

URT (2010). The National Elections Act. Dar es Salaam, Tanzania.

Yoon, M. Y. (2011). More Women in the Tanzanian Legislature: Do Numbers Matter? Journal of Contemporary African Studies, 29, 83-98.

https://doi.org/10.1080/02589001.2011.539011 